RASĀYAN J. Chem.

Vol. 14 | No. 2 |751-759| April - June | 2021

ISSN: 0974-1496 | e-ISSN: 0976-0083 | CODEN: RJCABP

http://www.rasayanjournal.com

http://www.rasayanjournal.co.in

\title{
PHYTOCHEMICAL SCREENING AND Py-GC-MS ANALYSIS OF AGARWOOD LEAVES (Aquilaria malaccensis Lamk.) CULTIVATED IN BAHOROK, LANGKAT REGENCY, NORTH SUMATRA, INDONESIA
}

\author{
Ridwanti Batubara ${ }^{1,2}$, Basuki Wirjosentono ${ }^{1, \bowtie}$, Amir Hamzah Siregar $^{1}$, \\ Urip Harahap ${ }^{3}$ and Tamrin ${ }^{1}$ \\ ${ }^{1}$ Department of Chemistry, Faculty of Mathematics and Natural Sciences Universitas Sumatera \\ Utara, Medan 20155, Sumatera Utara, Indonesia \\ ${ }^{2}$ Department of Forestry, Faculty of Forestry, Universitas Sumatera Utara, Medan 20155, \\ Sumatera Utara, Indonesia \\ ${ }^{3}$ Department of Pharmacology, Faculty of Pharmacy, Universitas Sumatera Utara, Medan 20155, \\ Sumatera Utara, Indonesia \\ Corresponding Author: basuki@usu.ac.id
}

\begin{abstract}
Agarwood is one of the common plants to be cultivated by the people in Langkat Regency, North Sumatra, Indonesia, with the species name Aquilaria malaccensis Lamk. This research aimed to determine the quality parameters of agarwood leaves and to investigate the chemical contents of agarwood leaves simplicia using phytochemical and PyGC-MS analysis. The collected agarwood leaves were identified and then classified into three types i.e. the young, mature, and mixed leaves. The agarwood leaves were then processed into agarwood leaves simplicia and extracted using ethanol 96\%. Phytochemical screening was also performed. The young leaves simplicia contained $8.94 \%$ moisture content, $18.39 \%$ water-soluble extract, $10.92 \%$ ethanol-soluble extract, $6.62 \%$ total ash and $0.53 \%$ acid insoluble ash. While the mature leave simplicia contained $8.02 \%$ moisture content, $22.89 \%$ water-soluble extract, $17.93 \%$ ethanol-soluble extract, $5.69 \%$ total ash and $0.97 \%$ acid insoluble ash. The mixed leaves simplicia contained $7.00 \%$ moisture content, $20.33 \%$ water-soluble extract, $19.67 \%$ ethanol-soluble extract, $7.53 \%$ total ash, and $0.77 \%$ acid insoluble ash. Phytochemical screening results that no significant difference in the young, mature and mixed, leaves, positively containing glycosides, steroids/triterpenoids, flavonoids and tannins. Furthermore, chromatogram data of Py-GC-MS analysis results showed that compounds with the highest concentrations in the young leaves simplicia were hexadecenoic acid (CAS) palmitic acid $(28.42 \%)$, in the mature leaves simplicia were octadecanoic acid (CAS) stearic acid (26.60\%) and in mixed leaves, simplicia were octadecanoic acid (CAS) stearic acid (16.04\%). Keywords: Agarwood leaves, Extract, Characterization, Phytochemical analysis, GCMS

RASĀYAN J. Chem., Vol. 14, No.2, 2021
\end{abstract}

\section{INTRODUCTION}

The development of agarwood utility values encourages the interest of industrialized countries to obtain agarwood at an ever-increasing selling price. The high demand and selling price encourages the community's efforts to change production patterns, from initially only utilizing and/or collecting from nature, to by the means of cultivation. The way to meet the demand and production of agarwood is by mass and sustainable planting of agarwood-producing trees (APT) species. Indonesia is a country that has a high diversity of agarwood-producing tree species (APT) compared to other countries in Asia. Agarwoodproducing trees (APT) planted in Indonesia have been recorded and mapped. Furthermore, APT plantations in Indonesia were established on a small scale and traditionally run by farmers. ${ }^{1}$

It is possible to produce agarwood from cultivated plants to be engineered through the technology of disease induction/inoculation according to the type of tree and the environment in which it is grown. During the cultivation process, the leaves of Aquilaria malaccensis Lamk are a byproduct that has not been optimally utilized and is considered a waste. People have consumed A. malaccensis leaves that are cultivated by the 
people in Bahorok, Langkat Regency, in the form of tea from boiling the dried leaves. It has been reported that agarwood leaves have antioxidant activity. ${ }^{2-5}$

Research results showed that the methanol extract of the old agarwood leaves of $A$. malaccensis Lamk was the most potent extract with an IC value of $19.62 \pm 1.49 \mu \mathrm{g} / \mathrm{mL}$ and the combined fraction of chloroform 1: 3: methanol and 100\% methanol showed the highest antioxidant activity with IC50 of $17.39 \pm 1.43$ $\mu \mathrm{g} / \mathrm{mL} .{ }^{6}$ The results of the study of gel preparations containing A. microcarpa leaf extract showed that the IC50 value for the gel extract of $26.39-28.94 \mu \mathrm{g} / \mathrm{mL}$, while for the gel fraction was $22.22-23.05 \mu \mathrm{g} / \mathrm{mL}$, both of which showed very high antioxidant activity. ${ }^{7}$

The ethanol extract of young leaves and mature leaves of agarwood type Wikstroemia tenuiramis Miq contains flavonoids, glycosides, steroids/triterpenoids and tannins. ${ }^{4}$ Agarwood leaves of type $A$. malaccensis that grow naturally from the village of Sigiring-giring contain terpenoids and saponins, while those from the village of S. kalangan II contain tannin and saponin compounds. ${ }^{3}$ The ethanol, ethyl acetate and $\mathrm{n}$-hexane fractions of $A$. malaccensis leaves contain flavonoids, terpenoids, phenolics, saponins and alkaloids, showing anti-cancer properties. ${ }^{8}$ The results obtained in the phytochemical test reveals that the water extract of agarwood leaves contains phenolic compounds, flavonoids, and steroids. ${ }^{9}$ The phytochemistry of two types of leaves of aloes-producing trees, types A. microcarpa and A. malaccensis, with and without inoculation by fungi, showed the presence of tannins, steroids, phenols, and flavonoids. ${ }^{10}$ The young and mature leaves of Borneo Agarwood (A. malaccensis) extracts revealed the presence of alkaloids and carbohydrate. ${ }^{11}$

Furthermore, agarwood leaves were reported to have antidiabetic, anti-inflammatory, antioxidant, antibacterial, and antiviral activity. ${ }^{6,7,12}$ The methanol extract of agarwood leaves was reported to contain more than a dozen chemical constituents including flavonoids, alkaloids, terpenoids and glycosides, and extractable secondary metabolite. ${ }^{13}$ Finally, the leaves of A. malaccensis show the ability to increase glucose uptake by increasing GLUT4 levels in skeletal muscle. Therefore, further research is needed to explore this agarwood leaf as a strong antidiabetic agent. ${ }^{12}$

Research on antioxidant activity of $A$. malaccensis Lamk. mature leaves extract showed that the methanolic extract was the most potent extract with an $\mathrm{IC}_{50}$ value of $19.62 \pm 1.49 \mu \mathrm{g} / \mathrm{mL}$, while the combined fraction of chloroform: methanol with a ratio of 1:3 and the fraction of $100 \%$ methanol showed the highest antioxidant activity with $\mathrm{IC}_{50}$ of $17.39 \pm 1.43 \mu \mathrm{g} / \mathrm{mL} .{ }^{6}$ Another research on antioxidant activity of the gel prepared containing $A$. microcarpa leaves extract showed the $\mathrm{IC}_{50}$ value of $26.39-28.94 \mu \mathrm{g} / \mathrm{mL}$ for the gel extract, and the $\mathrm{IC}_{50}$ value of $22.22-23.05 \mu \mathrm{g} / \mathrm{mL}$ for the gel fraction, representing very active antioxidant activity. ${ }^{8}$

Several chemical compounds contained in the Aquilaria leaves had been identified, including 2-(2phenilethyl) chromones, phenolic acids, steroids, terpenoids, pyranones, quinones, benzophenone, xanthonoid, flavonoids, and nucleosides. ${ }^{14}$ Mangiferin, genkwanin, and iriflophenone glycosides were generally found in $A$. crassna and $A$. sinensis leaves when extracted in ethanol using the maceration method and detected using liquid chromatography-mass spectrometry (LC-MS) and silica gel column chromatography (SGCC). ${ }^{13,15-19}$ Utilization of these leaves requires research series for future development, especially related to raw materials derived from cultivation. Fundamental research that needs to be done is to search for any chemical components contained in the agarwood leaves.

This research was conducted to study the characteristics and chemical components found in mixed, young, and mature leaves of agarwood which came from Bahorok, Langkat, North Sumatra.

\section{EXPERIMENTAL}

\section{Sampling Process and Analysis}

This research sampling was conducted in Pekan Bahorok Village, Bahorok District, Langkat Regency, North Sumatra, Indonesia. Phytochemical characterization and screening were carried out at the Laboratory of Pharmaceutical Biology, Faculty of Pharmacy, Universitas Sumatera Utara, Indonesia, whereas for determination of moisture content and extraction were carried out at the Forest Products Technology Laboratory of the Faculty of Forestry. Also, the GCMS was carried out at the Forest Product Research and Development Laboratory, Bogor. 
RASĀYAN J. Chem.

Vol. 14 | No. 2 |751-759| April - June | 2021

\section{Raw Material Preparation}

At this stage, the agarwood leaves were cleaned with distilled water, then spread on parchment paper until the water was absorbed. The materials were dried in a drying. The drying process was conducted by artificial drying using a drying cabinet with a temperature of $40-50{ }^{\circ} \mathrm{C}$. This drying was performed to get a simplicia that is not easily damaged, so it can be stored for a long time. Then, dried leaves were turned into powder using a blender. Simplicia that has become a powder was put into a sun-protected container before extraction and analysis.

\section{Water Content and Simplicia Characteristics}

The determination of water content was carried out using the gravimetric method. Simplicia characterization was performed for several investigations, including determination of water-soluble extract content, soluble extract content in ethanol, ash content, and acid insoluble ash content. ${ }^{20}$

\section{Characterization and Phytochemical Screening}

To start with, the moisture content of the sample was analyzed using the gravimetry method. Furthermore, simplicia identification was done by checking and observing macroscopically, water-soluble extract, ethanol-soluble extract, total ash and acid-insoluble ash. ${ }^{15}$ Phytochemical screening is a qualitative chemical examination of biologically active compounds found in simplicia and agarwood leaves extract. These compounds are organic compounds; therefore, screening is mainly intended for groups of organic compounds such as alkaloids, glycosides, flavonoids, steroids/terpenoids, tannins and saponins.

\section{Ethanol Extract of Agarwood (A. malaccensis Lamk.) Leaves}

The extract was made via maceration with ethanol $96 \%$. As much as $200 \mathrm{~g}$ of simplicia powder was put into a glass container, poured with $1500 \mathrm{~mL}$ of ethanol, covered, and left for 5 days protected from light with the occasional stirring process. After 5 days, the mixture was filtered and the pulp was washed with ethanol sufficiently to obtain $2000 \mathrm{~mL}$, then transferred into a closed vessel and left in a cool place protected from light for 2 days. Finally, it was then poured and filtered. The macerate was concentrated using a rotary evaporator at $40^{\circ} \mathrm{C}$ until a thick macerate was obtained. Then, it was dried using a freeze dryer to get a dry extract. Finally, The GC-MS analysis was conducted in Forest Research and Development Department, Bogor, Indonesia by utilizing a GC-MS pyrolysis machine.

\section{Moisture Content and Characterization}

\section{RESULTS AND DISCUSSION}

The moisture content needs to be determined because it is closely related to the quality of the prepared simplicia. Moisture content represents the water content in the simplicia. Determination of moisture content is also useful for estimating the durability or endurance of samples in storage.

Moisture contents of agarwood leaves after drying are presented in Table 1, the drying process was carried out by differentiating among young, mature and mixed leaves. These results had fulfilled SNI requirements that are not to exceed 12\% maximum. These results also met POM standards, that the simplicia moisture content does not exceed $10 \% .{ }^{21}$ Agarwood leaves simplicia samples were occupied the standardization requirements of simplicia moisture content which were not more than $10 \%$, where the highest moisture content was in young leaves samples which equal to $8.94 \%$. While the lowest one was found in the mixed leaves extract which is $7.00 \%$. Moisture content greatly affects the quality and characteristics of the extract and also the extraction process carried out.

Table-1: Simplicia Characterization Results

\begin{tabular}{c|c|c|c}
\hline \multirow{2}{*}{ Characteristics } & \multicolumn{3}{|c}{ Simplicia Examination Results (\%) } \\
\cline { 2 - 4 } & Young Leaves & Mature Leaves & Mixed Leaves \\
\hline Moisture Content & $8.94 \pm 1.09$ & $8.02 \pm 1.26$ & $7.00 \pm 0.43$ \\
\hline Water Soluble Extract Content & $18.39 \pm 5.26$ & $22.89 \pm 4.89$ & $20.33 \pm 0.29$ \\
\hline Ethanol Soluble Extract Content & $10.92 \pm 0.42$ & $17.93 \pm 0.77$ & $19.67 \pm 0.29$ \\
\hline Total Ash Content & $6.62 \pm 0.46$ & $5.69 \pm 0.19$ & $7.53 \pm 1.10$ \\
\hline Acid Insoluble Ash Content & $0.53 \pm 0.08$ & $0.97 \pm 0.05$ & $0.77 \pm 0.23$ \\
\hline
\end{tabular}


RASĀYAN J. Chem.

Vol. 14 | No. 2 |751-759| April - June | 2021

Determination of water-soluble extract content and ethanol-soluble extract content is aimed to show the amount of yield extract on each water and ethanol solvent one. Water-soluble materials consist of carbohydrates, salts, some vitamins, and some organic ingredients. Determination of this extracted content is very important because it can give descriptions of dissolved material amounts that had medicinal functions.

On the other hand, the determination of ash content aims to describe the amount of metal content in plants, while acid insoluble ash indicates the presence of silicate. Both metal and silicate come from soil and water that are sucked up by plant tissue. The values obtained in this research were under $1 \%$.

\section{Phytochemical Screening Results}

Agarwood leaves research was carried out to increase the benefits of the tree. Phytochemical screening was a preliminary study to determine secondary metabolites in plants. ${ }^{22}$ Phytochemical screening was carried out on both the simplicia powder of fresh agarwood leaves and the ethanol extracts, to know the groups of secondary metabolite compounds contained in agarwood leaves. The results of phytochemical screening can be seen in Table-2.

The results in Table-2 show that there is no difference in chemical compound results through phytochemical screening tests that were carried out on agarwood leaves extract. Phytochemical test results showed that the ethanol extract of agarwood leaves from Bahorok, Langkat regency has a group of secondary metabolites, that consists of flavonoids, tannins, and steroids/triterpenoids that potentially as antioxidants. The same secondary compounds were as well as found in mature, young, and mixed mature and young leaves.

Phytochemical screening results provide important information about the chemical compounds of agarwood leaves. After knowing the chemical compounds, it will be easier in determining the use, especially in advanced utilizations, such as for treatment.

Table-2: Phytochemical Screening Results Data

\begin{tabular}{c|c|c|c|c|c|c}
\hline \multirow{2}{*}{ Compounds } & \multicolumn{2}{|c|}{ Mixed Leaves } & \multicolumn{2}{c|}{ Young Leaves } & \multicolumn{2}{c}{ Mature Leaves } \\
\cline { 2 - 7 } & Simplicia & Extract & Simplicia & Extract & Simplicia & Extract \\
\hline Alcaloids & - & - & - & - & - & - \\
\hline Glycosides & + & + & + & + & + & + \\
\hline Steroids /triterpenoids & + & + & + & + & + & + \\
\hline Flavonoids & + & + & + & + & + & + \\
\hline Tannins & + & + & + & + & + & + \\
\hline Saponins & - & - & - & - & - & - \\
\hline Notes: += present; - absent
\end{tabular}

The glycoside compounds were found to be contained in cultivated agarwood leaves of $A$. malaccensis Lamk. Phytochemical investigations on the ethanol extract of $A$. sinensis leaves found five new benzophenone glycosides, aquilarinensides A-E. ${ }^{23} \mathrm{~A}$ new flavonoid glycoside, named aquisiflavoside, has also been obtained from the leaves of Aquilaria sinensis (Lour.). ${ }^{24}$ Glycosides are complex substances that contain sugar when hydrolyzed into glycons and aglycones (genin). Leaf extract of $A$. sinensis (Lour.) Gilg. has anti-analgesic and anti-inflammatory activity. ${ }^{25}$

Agarwood leaves were also reported to contain steroid / triterpenoid compounds. Steroids are secondary metabolites mostly analyzed in plants, as these are major constituents of plant pigments. ${ }^{26}$ Furthermore, agarwood leaves also contain flavonoid compounds. Flavonoids are water-soluble polyphenol molecules containing 15 carbon atoms present in plants. ${ }^{27}$ Flavonoids are polyphenolic compounds that can reduce free radical activity, also have antimutagenic activity and a dose-dependent protective effect against cyclophosphamide - the cause of DNA oxidative damage. ${ }^{28}$ Flavonoids are one of the best polyphenols, many of which have properties such as antioxidants, antimutagenic, anti-carcinogenic and antiinflammatory. ${ }^{29}$

The results of the phytochemical test of agarwood leaves were positive for tannin. The tannin content of $W$. tenuiramis and A. malaccensis was $4.95 \%$ and $5.62 \%$ respectively.30 The young leaves of agarwood W. tenuiramis contain tannins $1.079 \pm 0.001 \%$ and mature leaves contain $4.645 \pm 0.021 \%$ tannins. ${ }^{4}$ The tannins extract of Aloe vera showed an antiradical activity with percentage inhibition of about $74.17 \%$ at $6 \mathrm{mg}$ 
RASĀYAN J. Chem.

Vol. 14 | No. 2 |751-759| April - June | 2021

$/ \mathrm{mL} .{ }^{31}$ This is critical as tannins have the potential to act as chelating agents with plasmolytic effects and interfere with cell permeability. ${ }^{32}$

\section{Py GC-MS Analysis Results}

Based on the spectrogram data, the fragmentation pattern of each compound was obtained (Fig.-1, Fig.-2, and Fig.-3). Characteristic fragmentation patterns and basic peaks led to the structure of each compound. The fragmentation pattern of each compound showed that each of the young, mature, and mixed leaves extracts contained different and many compounds as shown in Table- 3,4 , and 5.

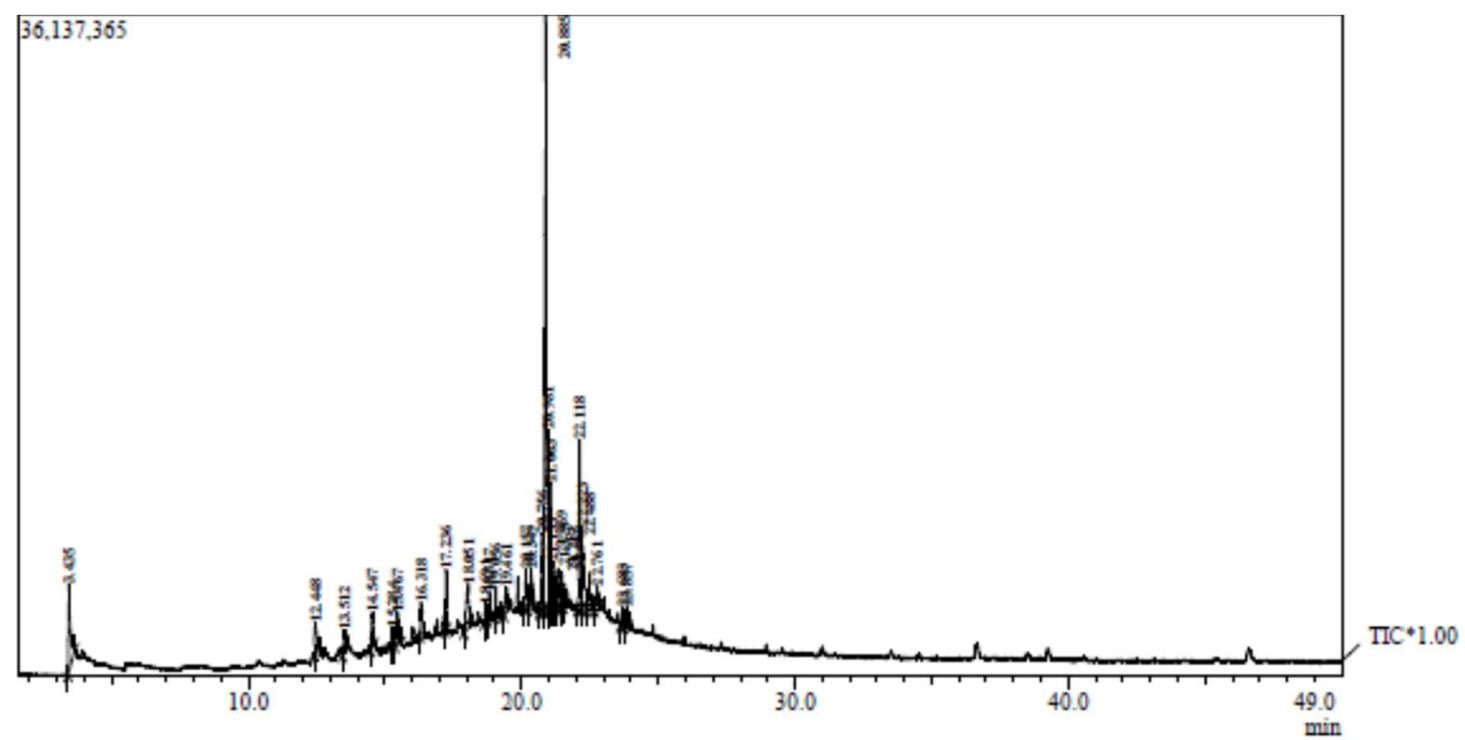

Fig.-1: GC-MS Chromatogram of Agarwood A. malaccensis Young Leaves

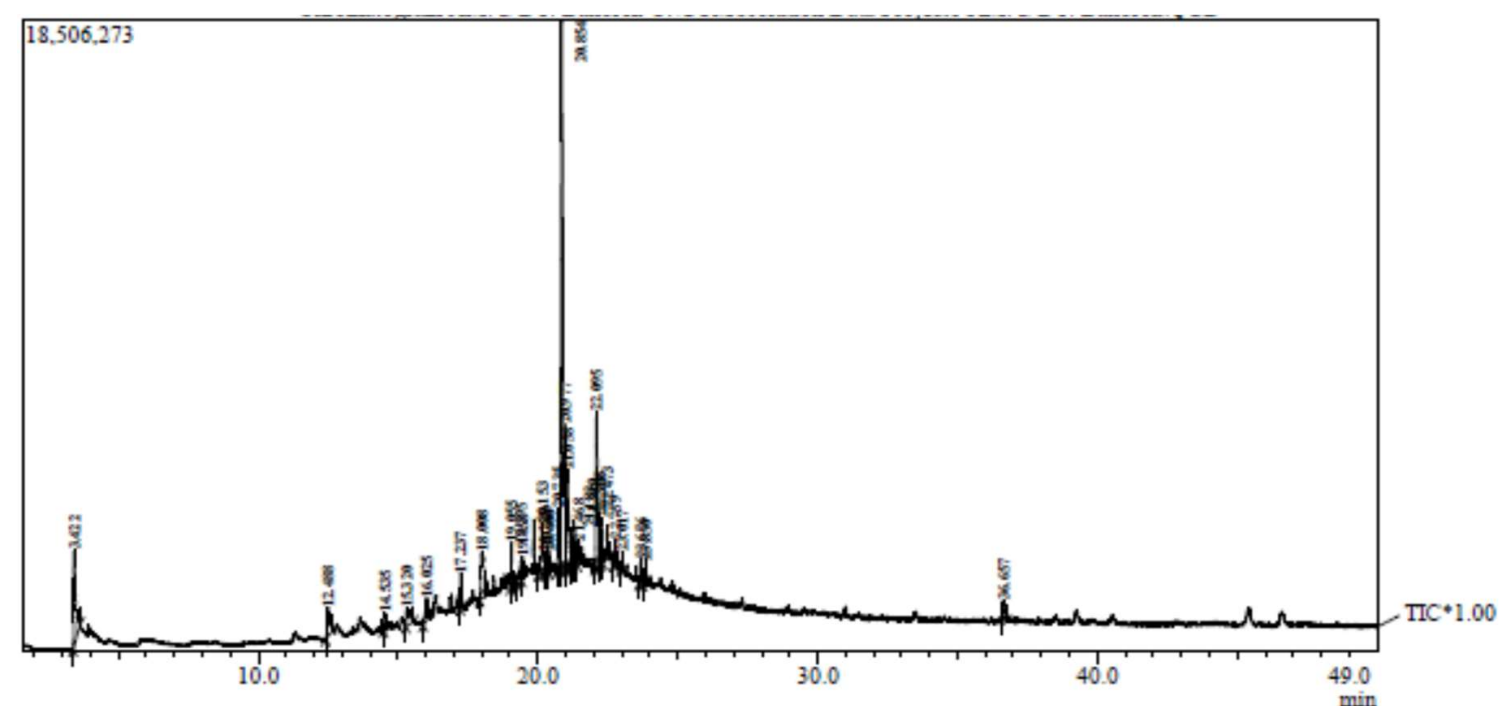

Fig.-2: GC-MS Chromatogram of Agarwood A. malaccensis Mature Leaves

Based on the chromatogram, there were 30 compounds identified in mature, young, and mixed leaves extracts. The compounds identified were not similar. The compound with the highest concentration in young leaves was hexadecanoic acid (CAS) palmitic acid (28.42\%), in mature leaves was octadecanoic acid (CAS) stearic acid (26.60\%) and in mixed leaves was octadecanoic acid (CAS) stearic acid (16.04\%). The content of the largest compound in the mature and the mixed leaves extracts was similar. The dominant compound that contained was acid, thus contributing to the antioxidant activity strength of agarwood leaves extract. 
RASĀYAN J. Chem.

Vol. 14 | No. 2 |751-759| April - June | 2021

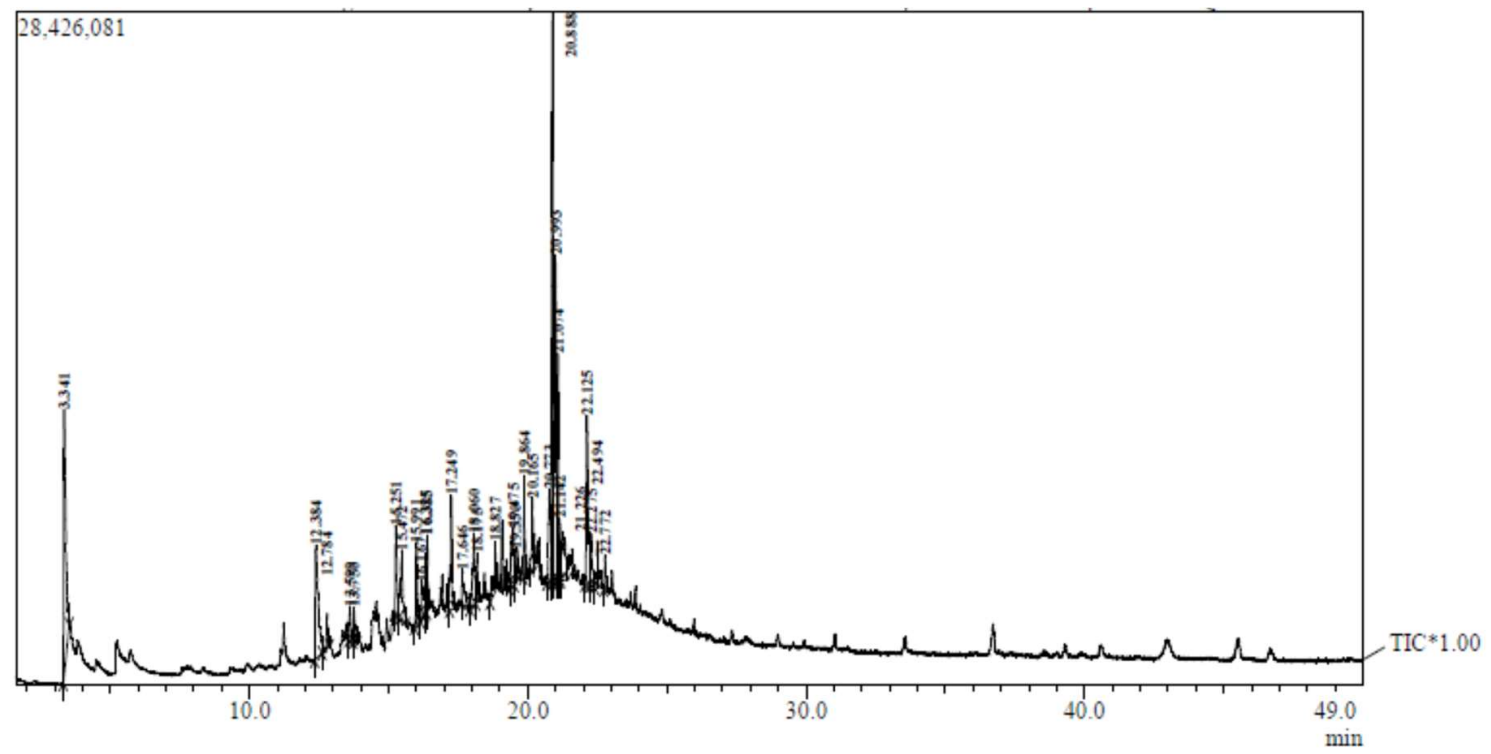

Fig.-3: GC-MS Chromatogram of Agarwood A. malaccensis Mixed Leaves

The dominant compounds detected on more than $3 \%$ of concentration for mixed leaves extract were carbon dioxide (CAS) dry ice, carbamic acid, phenyl ester (CAS) phenylcarbamate, decanoic acid (CAS) capric acid, 9-octadecenoic acid (Z) - (CAS) ) oleic acid, 9,12-octadecadienal (CAS), and octadecanoic acid (CAS) stearic acid. The dominant compounds detected in young leaves extract were trideuteroacetonitrile, carbamic acid, phenyl ester (CAS) phenylcarbamate, 3,4-hexanediol, 2,5-dimethyl- (CAS) 2,5-dimethyl3,4-hexandiol, 1,12 -tridecadiene (CAS), octadecanoic acid (CAS) stearic acid, 9,15-octadecadienoic acid, methyl ester (CAS) methyl 9,15-octadecad, 1,4-diaza-2,5-dioxo-3-isobutyl bicyclo [4.3.0] nonane and 9octadecenoic acid (Z) - (CAS) oleic acid. The dominant compounds detected immature leaves were carbon dioxide (CAS) dry ice, carbamic acid, phenyl ester (CAS) phenylcarbamate, 9-octadecenoic acid (Z) (CAS) oleic acid, 9,12-octadecadienal (CAS), octadecanoic acid (CAS) stearic acid, and 9,12octadecadienal (CAS).

Tabel-3: Chemical Compounds List from Agarwood A. malaccensis Young Leaves

\begin{tabular}{c|c|c|c|l}
\multicolumn{5}{c}{ Tabel-3: Chemical Compounds List from Agarwood A. malaccensis Young Leaves } \\
\hline Peak\# & R. Time & Area & Concentration (\%) & \multicolumn{1}{c}{ Peak Report TIC Name } \\
\hline 1 & 3.341 & 55410077 & 10.71 & Trideuteroacetonitrile \\
\hline 2 & 12.384 & 32360209 & 6.25 & Carbamic acid, phenyl ester (CAS) Phenyl carbamate \\
\hline 3 & 12.784 & 5350027 & 1.03 & 1-Octene (CAS) Caprylene \\
\hline 4 & 13.599 & 5671592 & 1.10 & Phenol, 2-methyl- (CAS) o-Cresol \\
\hline 5 & 13.750 & 4328810 & 0.84 & cis-1,3-Dideuterio-1,3-cyclohexandiamine \\
\hline 6 & 15.251 & 14269850 & 2.76 & Benzofuran, 2,3-dihydro- (CAS) 2,3-Dihydrobenzofuran \\
\hline 7 & 15.472 & 16863555 & 3.26 & $\begin{array}{l}\text { 3,4-Hexanediol, 2,5-dimethyl- (CAS) 2,5-Dimethyl-3,4- } \\
\text { hexandiol }\end{array}$ \\
\hline 8 & 15.991 & 11920398 & 2.30 & Benzonitrile, 2-methyl- (CAS) 1-Methyl-2-cyanobenzene \\
\hline 9 & 16.167 & 10504114 & 2.03 & 2-Methyl-2,3-divinyloxirane \\
\hline 10 & 16.325 & 6724498 & 1.30 & Phenol, 2,6-dimethoxy- (CAS) 2,6-Dimethoxyphenol \\
\hline 11 & 16.385 & 8795400 & 1.70 & Undecane, 2-methyl- (CAS) 2-Methylundecane \\
\hline 12 & 17.249 & 12868027 & 2.49 & Undecane, 2-methyl- (CAS) 2-Methylundecane \\
\hline 13 & 17.646 & 10176427 & 1.97 & $\begin{array}{l}\text { Benzoic acid, 3-hydroxy-, methyl ester (CAS) Methyl 3- } \\
\text { hydroxybenzoate }\end{array}$ \\
\hline 14 & 18.060 & 15420900 & 2.98 & 1-Octene (CAS) Caprylene \\
\hline 15 & 18.175 & 7067572 & 1.37 & 6,7-Dihydro-3-Nitro-5H-Cyclopenta[B]pyridin-2(1H)-ONE \\
\hline 16 & 18.827 & 9196045 & 1.78 & Undecane, 2-methyl- (CAS) 2-Methylundecane \\
\hline 17 & 19.475 & 13858728 & 2.68 & Tridecane (CAS) n-Tridecane \\
\hline 18 & 19.550 & 3448775 & 0.67 & Tridecane (CAS) n-Tridecane \\
\hline 19 & 19.864 & 8066482 & 1.56 & $\begin{array}{l}\text { 11-Tetradecen-1-ol, acetate, (Z)- (CAS) cis-11-Tetradecenyl } \\
\text { acetate }\end{array}$ \\
\hline 20 & 20.165 & 8548339 & 1.65 & $\begin{array}{l}\text { 11-Tetradecen-1-ol, acetate, (Z)- (CAS) cis-11-Tetradecenyl } \\
\text { acetate }\end{array}$ \\
\hline & & & & \begin{tabular}{l} 
156 \\
\hline
\end{tabular} \\
\hline
\end{tabular}


RASĀYAN J. Chem.

Vol. 14 | No. 2 |751-759| April - June | 2021

\begin{tabular}{|c|c|c|c|c|}
\hline 21 & 20.773 & 17541047 & 3.39 & 1,12-Tridecadiene (CAS) \\
\hline 22 & 20.888 & 82999997 & 16.04 & Octadecanoic acid (CAS) Stearic acid \\
\hline 23 & 20.993 & 53574605 & 10.35 & $\begin{array}{l}\text { 9,15-Octadecadienoic acid, methyl ester (CAS) Methyl-9,15- } \\
\text { octadecad }\end{array}$ \\
\hline 24 & 21.074 & 23054360 & 4.46 & 1,4-diaza-2,5-dioxo-3-isobutyl bicyclo[4.3.0]nonane \\
\hline 25 & 21.142 & 7061941 & 1.36 & 1,4-diaza-2,5-dioxo-3-isobutyl bicyclo[4.3.0]nonane \\
\hline 26 & 21.226 & 18776095 & 3.63 & 1,4-diaza-2,5-dioxo-3-isobutyl bicyclo[4.3.0]nonane \\
\hline 27 & 22.125 & 28539149 & 5.52 & 9-Octadecenoic acid (Z)- (CAS) Oleic acid \\
\hline 28 & 22.275 & 12902808 & 2.49 & Dodecane, 2-methyl- (CAS) 2-Methyldodecane \\
\hline 29 & 22.494 & 7632053 & 1.48 & 9-Octadecenamide, (Z)- (CAS) Oleoamide \\
\hline 30 & 22.772 & 4449810 & 0.86 & 9-Octadecenal (CAS) Octadecenyl aldehyde \\
\hline \multicolumn{5}{|c|}{ Tabel-4: Chemical Compounds List from Agarwood A. malaccensis Mature Leaves } \\
\hline Peak\# & R.Time & Area & Concentration $(\%)$ & Peak Report TIC Name \\
\hline 1 & 3.422 & 13492326 & 6.68 & Carbon dioxide (CAS) Dry ice \\
\hline 2 & 1.488 & 6066675 & 3.00 & Carbamic acid, phenyl ester (CAS) Phenyl carbamate \\
\hline 3 & 14.535 & 2155261 & 1.07 & Heptanoic acid (CAS) Heptoic acid \\
\hline 4 & 15.320 & 4832637 & 2.39 & Benzaldehyde, 4-methyl- (CAS) p-Tolualdehyde \\
\hline 5 & 16.025 & 3608578 & 1.79 & 7-Cyano(15N)-Cycloheptatriene \\
\hline 6 & 17.237 & 1900815 & 0.94 & Undecane, 2-methyl- (CAS) 2-Methylundecane \\
\hline 7 & 18.008 & 10388169 & 5.14 & Decanoic acid (CAS) Capric acid \\
\hline 8 & 19.055 & 2418305 & 1.20 & 1-Dodecene (CAS) Adacene 12 \\
\hline 9 & 19.395 & 2778187 & 1.38 & 6-Methylbicyclo[4.4.0]dec-2-ene-4,7-dione \\
\hline 10 & 19.458 & 1925258 & 0.95 & Undecanoic acid (CAS) Undecylic acid \\
\hline 11 & 20.153 & 7107921 & 3.52 & 9-Octadecenoic acid (Z)- (CAS) Oleic acid \\
\hline 12 & 20.225 & 745288 & 0.37 & Decyl disulfide \\
\hline 13 & 20.339 & 4292720 & 2.13 & $\begin{array}{l}\text { 2,5-Hexanediol, 2,5-dimethyl- (CAS) 2,5-Dimethyl-2,5- } \\
\text { hexanediol }\end{array}$ \\
\hline 14 & 20.400 & 525909 & 0.26 & Undecanenitrile (CAS) N-Decylcyanide \\
\hline 15 & 20.735 & 7145027 & 3.54 & 9,12-Octadecadienal (CAS) \\
\hline 16 & 20.854 & 53733537 & 26.6 & Octadecanoic acid (CAS) Stearic acid \\
\hline 17 & 20.977 & 12542454 & 6.21 & 9,12-Octadecadienal (CAS) \\
\hline 18 & 21.058 & 10160056 & 5.03 & 9,12-Octadecadienal (CAS) \\
\hline 19 & 21.183 & 4908914 & 2.43 & 1,4-diaza-2,5-dioxo-3-isobutyl bicyclo[4.3.0]nonane \\
\hline 20 & 21.300 & 5883103 & 2.91 & 1,6-Heptadiene, 5-deutero-3,3,6-trimethyl- \\
\hline 21 & 21.468 & 2458442 & 1.22 & Allyl heptanoate \\
\hline 22 & 22.095 & 17957866 & 8.89 & 9-Octadecenoic acid (Z)- (CAS) Oleic acid \\
\hline 23 & 22.208 & 4524959 & 2.24 & Octadecanoic acid (CAS) Stearic acid \\
\hline 24 & 22.267 & 4211912 & 2.09 & Nonadecane, 2-methyl-(CAS) 2-Methylnonadecane \\
\hline 25 & 22.473 & 4198023 & 2.08 & 9-Octadecenamide, $(\mathrm{Z})$ - (CAS) Oleoamide \\
\hline 26 & 22.759 & 2731650 & 1.35 & Cyclopentaneundecanoic acid \\
\hline 27 & 23.017 & 1049991 & 0.52 & Decane, 2,9-dimethyl-(CAS) 2,9-Dimethyldecane \\
\hline 28 & 23.676 & 2249731 & 1.11 & 2L,4L-Dihydroxyeicosane \\
\hline 29 & 23.850 & 2563762 & 1.27 & Tetradecane (CAS) n-Tetradecane \\
\hline 30 & 36.657 & 3422941 & 1.69 & Dotriacontane (CAS) n-Dotriacontane \\
\hline \multicolumn{5}{|c|}{ Tabel-5: Chemical Compounds List from Agarwood A. malaccensis Mixed Leaves } \\
\hline Peak\# & R. Time & Area & Concentration $(\%)$ & Peak Report TIC Name \\
\hline 1 & 3.422 & 13492326 & 6.68 & Carbon dioxide (CAS) Dry ice \\
\hline 2 & 12.488 & 6066675 & 3.00 & Carbamic acid, phenyl ester (CAS) Phenyl carbamate \\
\hline 3 & 14.535 & 2155261 & 1.07 & Heptanoic acid (CAS) Heptoic acid \\
\hline 4 & 15.320 & 4832637 & 2.39 & Benzaldehyde, 4-methyl-(CAS) p-Tolualdehyde \\
\hline 5 & 16.025 & 3608578 & 1.79 & 7-Cyano(15N)-Cycloheptatriene \\
\hline 6 & 17.237 & 1900815 & 0.94 & Undecane, 2-methyl- (CAS) 2-Methylundecane \\
\hline 7 & 18.008 & 10388169 & 5.14 & Decanoic acid (CAS) Capric acid \\
\hline 8 & 19.055 & 2418305 & 1.20 & 1-Dodecene (CAS) Adacene 12 \\
\hline 9 & 19.395 & 2778187 & 1.38 & 6-Methylbicyclo[4.4.0]dec-2-ene-4,7-dione \\
\hline 10 & 19.458 & 1925258 & 0.95 & Undecanoic acid (CAS) Undecylic acid \\
\hline 11 & 20.153 & 7107921 & 3.52 & 9-Octadecenoic acid (Z)- (CAS) Oleic acid \\
\hline 12 & 20.225 & 745288 & 0.37 & Decyl disulfide \\
\hline 13 & 20.339 & 4292720 & 2.13 & $\begin{array}{l}\text { 2,5-Hexanediol, 2,5-dimethyl- (CAS) 2,5-Dimethyl-2,5- } \\
\text { hexanediol }\end{array}$ \\
\hline
\end{tabular}


RASĀYAN J. Chem.

Vol. 14 | No. 2 |751-759| April - June | 2021

\begin{tabular}{l|l|l|l|l}
\hline 14 & 20.400 & 525909 & 0.26 & Undecanenitrile (CAS) N-Decyccyanide \\
\hline 15 & 20.735 & 7145027 & 3.54 & 9,12-Octadecadienal (CAS) \\
\hline 16 & 20.854 & 53733537 & 26.6 & Octadecanoic acid (CAS) Stearic acid \\
\hline 17 & 20.977 & 12542454 & 6.21 & 9,12-Octadecadienal (CAS) \\
\hline 18 & 21.058 & 10160056 & 5.03 & 9,12-Octadecadienal (CAS) \\
\hline 19 & 21.183 & 4908914 & 2.43 & 1,4-diaza-2,5-dioxo-3-isobutyl bicyclo[4.3.0]nonane \\
\hline 20 & 21.300 & 5883103 & 2.91 & 1,6-Heptadiene, 5-Deutero-3,3,6-trimethyl \\
\hline 22 & 21.468 & 2458442 & 1.22 & Allyl heptanoate \\
\hline 23 & 22.095 & 17957866 & 8.89 & 9-Octadecenoic acid (Z)- (CAS) Oleic acid \\
\hline 24 & 22.208 & 4524959 & 2.24 & Octadecanoic acid (CAS) Stearic acid \\
\hline 25 & 22.473 & 4211912 & 2.09 & Nonadecane, 2-methyl- (CAS) 2-Methylnonadecane \\
\hline 26 & 22.759 & 2731650 & 2.08 & 9-Octadecenamide, (Z)- (CAS) Oleoamide \\
\hline 27 & 23.017 & 1049991 & 1.35 & Cyclopentaneundecanoic acid (CAS) \\
\hline 28 & 23.676 & 2249731 & 0.52 & Decane, 2,9-dimethyl- (CAS) 2,9-Dimethyldecane \\
\hline 29 & 23.850 & 2563762 & 1.11 & 2L,4L-Dihydroxyeicosane \\
\hline 30 & 36.657 & 3422941 & 1.27 & Tetradecane (CAS) n-Tetradecane \\
\hline
\end{tabular}

The chemical compound detected from Py-GC-MS was carbamic acid. Previous research showed that the carbamic acid ethyl ester compound had antimicrobial and antifungal bioactivity. ${ }^{33}$ Phenyl carbamate from the Library has but unspecified activity in modifying hemoglobin form and has anticonvulsant activity in Swiss Mus musculus mice. As a comparison, gas chromatography-mass spectrometry (GC-MS) analysis of the plant extracts led to the identification of 14 components from the two types of agarwood leaves extracts. ${ }^{34}$

\section{CONCLUSION}

The qualities of agarwood leave simplicia extract made from young, mature, or mixed leaves were suitable following MMI standards. Phytochemical analysis results showed that the young, mature, and mixed leaves contain flavonoids, glycosides, tannins, and triterpenoids. Furthermore, GC-MS analysis results of chemical compounds showed that agarwood leaves are potentially available as raw materials for pharmaceutical and antimicrobial therapeutic which need to be further studied.

\section{ACKNOWLEDGEMENT}

The authors would like to thank the Rector of Univesitas Sumatera Utara for research funding provided via TALENTA USU 2019 on the scheme of programs of the Professor Funding Program.

\section{REFERENCES}

1. M. Turjaman and A. Hidayat, In IOP Conference Series: Earth and Environmental Science, Indonesia, 54, 012062(2017), DOI:10.1088/1755-1315/54/1/012062

2. Surjanto, R. Batubara, T. I. Hanum, and E. Julianti, In IOP Conference Series: Earth and Environmental Science, Indonesia, 305, 012061(2019), DOI:10.1088/1755-1315/305/1/012061

3. Surjanto, R. Batubara, T. I. Hanum, and W. Pulungan, In IOP Conf Series: Earth and Environmental Science, Indonesia, 260, 012101(2019), DOI:10.1088/1755-1315/260/1/012101

4. R. Batubara, Surjanto, T. I. Hanum, A. Handika and O. Afandi, Biodiversitas, 21(4), 1588(2020), DOI: 10.13057/biodiv/d210440

5. R. Batubara, T. I. Hanum, O. Afandi, and H. S. Wahyuni, Biodiversitas 21(10), 4616(2020), DOI: $10.13057 /$ biodiv/d211020

6. H. Hendra, S. Moeljopawiro, and T. R. Nuringtyas, In AIP Conference Proceedings for Antioxidant and Antibacterial Activities of Agarwood (Aquilariamalaccensis Lamk.) Leaves, 1755, 140004-1140004-9(2016), DOI:10.1063/1.4958565

7. R. Sari, M. Muhani, and I. Fajriati, Pharmaceutical Science Research, 4(3), 143(2017), DOI:10.7454/psr.v4i3.3756

8. Fatmawati and R. Hidayat, European Journal of Pharmaceutical and Medical Research, 3(1), 46(2016).

9. A. Parwata, P. Manuaba, S. Yasa, and I. G. N. G. Bidura, Journal of Biological and Chemical Research, 33(1), 294(2016).

10. K. S. Dewi, Master Thesis, Bogor Agricultural University, Bogor, Indonesia (2013). 
RASĀYAN J. Chem.

Vol. 14 | No. 2 |751-759| April - June | 2021

11. R. Maharani, A. Fernandes, M. Turjaman, G. Lukmandaru, and H. Kuspradini, International Journal of Pharmacognosy and Phytochemical Research, 8(10), 1576(2016).

12. F. Said, M. T. Kamaluddin, and Theodorus, International Journal of Health Sciences \& Research, 6(7),162(2016).

13. S. C. Wang, F. Wang, and C. H. Yue, Biochemical Systematics and Ecology, 61, 458(2015) DOI: $10.1016 /$ j.bse.2015.07.022

14. A. Z. Adam, S. H. Lee, and R. Mohamed, Journal of Herbal Medicine, 10, 37(2017), DOI:10.1016/j.hermed.2017.06.002

15. H. Wang, M. Zhou, J. Lu, and B. Yu, Chemistry and Industry of Forest Products, 28, 1(2008).

16. J. Qi, J. J. Lu, J. H. Liu, and B.Y. Yu, Chemical and Pharmacentical Bulletin, 57, 134(2009), DOI: $10.1248 / \mathrm{cpb} .57 .134$

17. J. Feng, X. W. Yang, and R. F. Wang, Phytochemistry, 72(2-3), 242(2011), DOI:10.1016/j.phytochem.2010.11.025

18. T. Ito, M. Kakino, S. Tazawa, M. Oyama, H. Maruyama, Y. Araki, H. Hara, and M. Iinuma, Food Science and Technology Research, 18(2), 259(2012).

19. Q. Yu, J. Qi, H. X. Yu, L. L. Chen, J. P. Kou, S. J. Liu, and B. Y. Yu, Phytochemical Analysis, 24, 349(2013), DOI: 10.1002/pca.2416

20. Ministry of Health of the Republic of Indonesia, Common Standard Parameters of Medicinal Plant Extracts, (2000).

21. Ministry of Health of the Republic of Indonesia, DG of Drug and Food Control, Materia Medika, Jakarta, pp.321-326, 333-337(1995).

22. C. Nuraskin, Marlina, R. Idroes, C. Soraya, and Djufri, Rasayan Journal of Chemistry, 13(1), 18(2020), DOI: $10.31788 /$ RJC.2020.1315434

23. J. Sun, S. Wang, F. Xia, K. Y. Wang, J. M. Chen, and P. F Tu, Chinese Chemical Letters, 25, 1573(2014), DOI: 10.1016/j.cclet.2014.07.013

24. X. B. Yang, J. Feng, X. Yanga, B. Zhao, and J. Liub, Journal of Asian Natural Products Research, 14(9), 867(2012), DOI:10.1080/10286020.2012.701209

25. M. Zhou, H. Wang, Suolangjiba, J. Kou and B. Yu, Journal of Ethnopharmacology, 117(2), 345(2008), DOI: $10.1016 /$ j.jep.2008.02.005

26. D. G. R. Aruan, T. Barus, G. Haro, and P. Simanjuntak, Rasayan Journal of Chemistry, 12(2), 947(2019), DOI: 10.31788/RJC.2019.1225204

27. T. D. Olawole, A. T. Olalere, O. A. Adeyemi, O. Okwumabua, and I. S. Afolabi, Rasayan Journal of Chemistry, 12(2), 523(2019), DOI:10.31788/RJC.2019.1224066

28. Sumaiyah, Masfria, and A. Dalimunthe, Rasayan Journal of Chemistry, 11(2), 505(2018), DOI: $10.31788 /$ RJC.2018.1122068

29. D. R. Jenifer and B. R. Malath, Rasayan Journal of Chemistry, 12(2), 630(2019), DOI: 10.31788/RJC.2019.122513

30. R. Batubara, T. I. Hanum, and Surjanto, In AIP Conference Proceedings, 2049, 030009(2018), DOI: $10.1063 / 1.5082510$

31. B. Benzidia, M. Barbouchi, H. Hammouch, N. Belahbib, M. Zouarhi, H. Erramli, N. A. Daoud, N. Badrane, and N. Hajjaji, Journal of King Saud University - Science, 31(4), 1175(2019), DOI: $10.1016 /$ j.jksus.2018.05.022

32. G. Saragih, Tamrin, Marpongahtun, D. Y. Nasution, and Abdillah, Rasayan Journal of Chemistry, 13(1), 476(2020), DOI:10.31788/RJC.2020.1315524

33. N. Zannata, D. M. Borchhardt, S. H. Alves, H. S. Coelho, A. M. C. Squizani, T. M. Marchi, H. G. Bonacorsoa, and M. A. P. Martinsa. Bioorganic \& Medicinal Chemistry 14, 3174(2006), DOI: 10.1016/j.bmc.2005.12.031

34. A. S. Khalil, A. A. Rahim, K. K. Taha, and K. B. Abdallah, Journal of Applied and Industrial Science, 1(3), 78(2013).

[RJC-6021/2020] 